\title{
Tetra-arsenic tetra-sulfide induces cell cycle arrest and apoptosis in retinoic acid-resistant acute promyelocytic leukemia cells
}

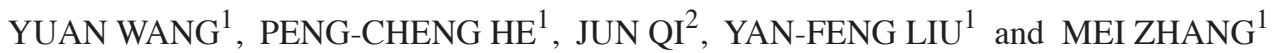 \\ ${ }^{1}$ Department of Hematology, The First Affiliated Hospital, Xi'an Jiaotong University Medical College; \\ ${ }^{2}$ Institute of Xi'an Blood Bank, Shaanxi Blood Center, Xi'an, Shaanxi 710061, P.R. China
}

Received March 24, 2015; Accepted May 14, 2015

DOI: $10.3892 /$ br. 2015.466

\begin{abstract}
Previous studies have shown that the therapeutic action of tetra-arsenic tetra-sulfide $\left(\mathrm{As}_{4} \mathrm{~S}_{4}\right)$ is effective for acute promyelocytic leukemia. However, the molecular mechanism of the action of $\mathrm{As}_{4} \mathrm{~S}_{4}$ in retinoic acid-resistant acute promyelocytic leukemia (APL) therapy remains unclear. In the present study, the signaling of the cytotoxic effects induced by $\mathrm{As}_{4} \mathrm{~S}_{4}$ on retinoic acid-resistant APL NB4-R1 cells was investigated. A time-dependent increase in cell death and DNA cleavage was observed following $\mathrm{As}_{4} \mathrm{~S}_{4}$ treatment. Changes in B-cell lymphoma 2 and Bax accompanied by the activation of caspase-3 and cleavage of poly ADP-ribose polymerase were observed as actions of $\mathrm{As}_{4} \mathrm{~S}_{4} . \mathrm{As}_{4} \mathrm{~S}_{4}$ induced an accumulation of NB4-R1 cells in the $\mathrm{S}$ and $\mathrm{G}_{2} / \mathrm{M}$ phases, as detected by flow cytometry. Therefore, the present results suggest that $\mathrm{As}_{4} \mathrm{~S}_{4}$-mediated apoptosis in NB4-R1 cells involves a mitochondria-dependent pathway.
\end{abstract}

\section{Introduction}

Acute promyelocytic leukemia (APL) is a form of acute myeloid leukemia, which has been identified as the $\mathrm{M}_{3}$ subtype. A unique chromosome translocation $\mathrm{t}(15 ; 17)(\mathrm{q} 22 ; \mathrm{q} 21)$ found in the majority of APL patients leads to the formation of the promyelocytic leukemia retinoic acid receptor $\alpha(\operatorname{PML}-\mathrm{RAR} \alpha)$ fusion gene (1). The fusion protein encoded by the PML-RAR $\alpha$ gene polymerizes and combines with retinoid-X receptor. The resultant protein complexes enhance histone deacetylase, thus repressing the transcription of the gene and disrupting the retinoic acid signal pathway under physiological concentrations of retinoic acid (1). This change results in the excessive growth

Correspondence to: Professor Mei Zhang, Department of Hematology, The First Affiliated Hospital, Xi'an Jiaotong University Medical College, 277 Yanta West Road, Xi'an, Shaanxi 710061, P.R. China

E-mail: meizhang_med@163.com

Key words: tetra-arsenic tetra-sulfide, NB4-R1 cells, acute promyelocytic leukemia, cell cycle, apoptosis of malignant promyelocytes and an inhibition of granulocyte differentiation.

All-trans retinoic acid (ATRA) as a successful model of differentiation therapy has improved the curative effect and extended the survival time of patients with APL. Clinical data has shown that the application of ATRA combined with chemotherapy increases the clinical complete response rate to $\leq 95 \%$ and the 2-year event-free survival rate was $86 \%$ (2). However, fatal retinoic acid syndrome and ATRA resistance in the majority of patients ultimately leads to treatment failure. Additionally, $31 \%$ of patients administered ATRA combined with chemotherapy relapse within 4-5 years after complete remission (3). Therefore, it is essential to identify new drugs for APL patients.

Arsenic trioxide $\left(\mathrm{As}_{2} \mathrm{O}_{3}\right)$ and tetra-arsenic tetra-sulfide $\left(\mathrm{As}_{4} \mathrm{~S}_{4}\right)$, as traditional medicines, have been used widely for the treatment of newly diagnosed and relapse APL. The side effects, such as fluid retention, skin rashes, leukocytosis, gastrointestinal discomfort, pulmonary infiltrates, neuropathy, prolongation of the corrected QT interval, liver function abnormality and sudden death, make it difficult for APL patients to accept $\mathrm{As}_{2} \mathrm{O}_{3}$ as a single agent for long-term treatment (4). Therefore, $\mathrm{As}_{2} \mathrm{O}_{3}$ should be incorporated into combination medications with ATRA or used as a salvage therapy for relapse APL patients.

$\mathrm{As}_{4} \mathrm{~S}_{4}$, which exerts similar effectiveness and less toxicity, provides not only a better quality-of-life, but is also advantageous in cytogenetic remission and PML-RAR $\alpha$ reversion for newly diagnosed and hematological relapse patients. Following a single application of $\mathrm{As}_{4} \mathrm{~S}_{4}$, the leukemia-free survival rate (LFS) for 1 and 3 years reached 86.1 and 76.6\%, respectively, among newly diagnosed APL patients, with a median follow-up time of 13.5 months. In addition, the LFS for 1 and 6 years was 96.7 and $87.4 \%$ for the hematological complete remission group, with a median follow-up of 23 months (5). A previous study suggested that the LFS of APL patients at 2 years treated with $\mathrm{As}_{4} \mathrm{~S}_{4}$ is higher than for those treated with $\mathrm{As}_{2} \mathrm{O}_{3}$ (6). Therefore, oral $\mathrm{As}_{4} \mathrm{~S}_{4}$ is not inferior to intravenous $\mathrm{As}_{2} \mathrm{O}_{3}$ as an effective treatment for APL and may be considered a routine treatment option for the appropriate patients. The exact molecular mechanism of the drug's action remains unclear and warrants further investigation. The aim of the present study was to characterize the toxicity and apoptosis induced by $\mathrm{As}_{4} \mathrm{~S}_{4}$ in a specific human APL NB4-R1 cell line that exhibits resistance to ATRA. 


\section{Materials and methods}

Cell culture and reagents. The NB4-R1 APL-derived cells from an RA-resistant promyelocytic cell line were generously supplied by Shanghai Second Medical College (Shanghai, China). The NB4-R1 cells were cultured in RPMI-1640 (Gibco-BRL, Carlsbad, CA, USA) medium supplemented with $10 \%$ heat-inactivated (at $56^{\circ} \mathrm{C}$ for $30 \mathrm{~min}$ ) fetal bovine serum, $100 \mathrm{U} / \mathrm{ml}$ penicillin and $100 \mu \mathrm{g} / \mathrm{ml}$ streptomycin, and maintained in a $5 \% \mathrm{CO}_{2}$ humidified atmosphere at $37^{\circ} \mathrm{C}$. The cells were grown at an optimal cell density between $5 \times 10^{5}$ and $1 \times 10^{6} / \mathrm{ml}$. Cell viability was evaluated via trypan blue dye exclusion assays and the cell survival rate was $>95 \%$. $\mathrm{As}_{4} \mathrm{~S}_{4}$ (Xi'an Traditional Chinese Drug Company, Xi'an, China) stock solution was obtained by dissolving in the $1.0 \mathrm{M}$ $\mathrm{NaOH}$ assistant agent. According to the $\mathrm{IC}_{50}$ of NB4-R1 cells in our previous study (7), the exponentially growing cells were treated with $25 \mu \mathrm{mol} / 1 \mathrm{As}_{4} \mathrm{~S}_{4}$ for 0,24 or $48 \mathrm{~h}$ and the cells were analyzed via flow cytometry, DNA ladder electrophoresis and western blot analysis.

\section{Measurement of apoptosis}

Annexin V-FLUOS/propidium iodide (PI) binding study using flow cytometry. Flow cytometric analysis using Annexin V-FLUOS and PI (Roche Custom Biotech, Indianapolis, IN, USA) was performed to differentiate between live, apoptotic and necrotic cells following treatment with $\mathrm{As}_{4} \mathrm{~S}_{4}$. Subsequent to the treatment with $25 \mu \mathrm{mol} / 1 \mathrm{As}_{4} \mathrm{~S}_{4}$ for 0 , 24 or $48 \mathrm{~h}, 1 \times 10^{6}$ cultured cells were harvested and washed twice with cold phosphate-buffered saline (PBS). The cells were centrifuged at $200 \mathrm{xg}$ for $5 \mathrm{~min}$ at $4^{\circ} \mathrm{C}$ and re-suspended in $100 \mu \mathrm{l}$ of Annexin V-FLUOS/PI labeling solution for 10-15 min in the dark at room temperature. The stained cell suspension was immediately analyzed using a flow cytometer (BD Biosciences FACSCalibur double laser flow cytometer; BD Biosciences, Franklin Lakes, NJ, USA). The data analysis was performed using the CellQuest software program (BD Biosciences).

DNA ladder agarose gel electrophoresis. DNA ladder fragmentation reflecting the endonuclease activity is a characteristic feature of apoptosis. After incubation for 0,24 or $48 \mathrm{~h}$ with $\mathrm{As}_{4} \mathrm{~S}_{4}$, the NB4-R1 cells were collected and washed twice with PBS. Subsequently, $1 \times 10^{6}$ cells were solubilized and the chromosomal DNA was extracted and purified using an Apoptotic DNA Ladder kit (Beyotime Institute of Biotechnology, Jiangsu, China) according to the manufacturer's instructions. The DNA samples were electrophoresed on a $1.5 \%$ agarose gel containing $1 \mathrm{mg} / \mathrm{ml}$ ethidium bromide at $60 \mathrm{~V}$ for $2 \mathrm{~h}$. The apoptotic DNA fragments were analyzed and photographed using a Quantity One gel image analysis system (ChemiDOC XRS; Bio-Rad, Richmond, CA. USA).

Cell cycle analysis. The cell cycle distribution was analyzed via flow cytometry (BD Biosciences FACSCalibur double laser flow cytometer). Following treatment with $\mathrm{As}_{4} \mathrm{~S}_{4}$ for 0 , 24 or $48 \mathrm{~h}$, the NB4-R1 cells $\left(1 \times 10^{6}\right)$ were harvested and washed twice with ice-cold PBS. The cells were suspended gently in $70 \%$ chilled ethanol at $-20^{\circ} \mathrm{C}$ overnight. After washing with PBS, the cells were re-suspended in $500 \mu 1$
PBS containing PI $(50 \mu \mathrm{g} / \mathrm{ml})$ and RNase $(50 \mu \mathrm{g} / \mathrm{ml})$, and were incubated for $30 \mathrm{~min}$ at room temperature in the dark. The cell cycle phase distribution of each experiment was analyzed using 10,000 cells per sample. The proportion of cells in the $G_{0} / G_{1}, S$ and $G_{2} / M$ phases were represented as DNA histograms.

Western blot analysis. After treatment with $25 \mu \mathrm{mol} / 1 \mathrm{As}_{4} \mathrm{~S}_{4}$ for 0,24 or $48 \mathrm{~h}$, the cultured cells were harvested and washed three times with cold PBS. Subsequently, the cells were solubilized in radioimmunoprecipitation assay buffer containing a protease inhibitor cocktail (Sigma, St. Louis, MO, USA). After incubation on ice for $10 \mathrm{~min}$, the cell suspension was centrifuged for protein at $15,500 \mathrm{xg}$ for $15 \mathrm{~min}$ at $4^{\circ} \mathrm{C}$. The protein $(30 \mu \mathrm{g})$ was separated on $10 \%$ SDS-PAGE and transferred to a nitrocellulose membrane at $110 \mathrm{~V}$ for $2 \mathrm{~h}$. The non-specific binding sites on the membranes were blocked with 5\% (w/v) skimmed milk in Tris-buffered saline (TBS): [20 mmol/l Tris- $\mathrm{HCl}$ and $200 \mathrm{mmol} / \mathrm{l} \mathrm{NaCl}(\mathrm{pH}$ 7.6)] for $2 \mathrm{~h}$ under gentle agitation at room temperature. Subsequently, the membranes were incubated with the relevant primary antibodies [poly ADP-ribose polymerase (PARP) rabbit monoclonal, 1:10,000; Cell Signaling Technology, Inc., Danvers, MA, USA; B-cell lymphoma 2 (Bcl-2) mouse monoclonal, 1:1,000; Bax rabbit monoclonal, 1:1,000; caspase-3 rabbit monoclonal, 1:1,000; GAPDH mouse monoclonal, 1:10,000; Santa Cruz Biotechnology, Inc., Dallas, TX, USA] directed against the protein or enzyme of interest for $1 \mathrm{~h}$ at room temperature and subsequently at $4^{\circ} \mathrm{C}$ overnight. The membranes were washed extensively with TBS containing $0.05 \%$ Tween-20 (v/v) (TBST) and incubated with the appropriate horseradish peroxidase-conjugated secondary antibody (Santa Cruz Biotechnology, Inc.) for $1 \mathrm{~h}$ at room temperature. Following washing with TBST, the membranes were incubated under chemiluminescence and wrapped in clear plastic wrap for film exposure. The bands on the immunoblots were quantified using Quantity One version 4.6.2 software (Bio-Rad). The protein expression of each sample was internally normalized to GAPDH and the quantity was compared with the expression of the control groups.

Statistical analysis. Experiments were performed in duplicates or triplicates of $\geq 3$ independent experiments and the results are presented as the mean \pm standard deviation. Statistical analysis between groups was carried out via a one-way analysis of variance using SPSS 19.0 software (IBM Corp., Armonk, NY, USA). $\mathrm{P}<0.05$ was considered to indicate a statistically significant difference.

\section{Results}

$\mathrm{As}_{4} \mathrm{~S}_{4}$ induces NB4-R1 cell apoptosis in a time-dependent manner. Apoptotic characterization was performed in the $\mathrm{As}_{4} \mathrm{~S}_{4}$-treated cells via Annexin V-FLUOS and PI double staining and the samples were analyzed via flow cytometry. The data revealed that the untreated cells showed normal cell viability. In contrast to the control cells, the percentage of early apoptotic cells treated with $25 \mu \mathrm{mol} / 1 \mathrm{As}_{4} \mathrm{~S}_{4}$ for 24 or $48 \mathrm{~h}$ (Annexin $\mathrm{V}^{+} / \mathrm{PI}^{-}$, in the lower right quadrant) significantly increased from 0.00 to 24.49 and $47.41 \%(\mathrm{P}<0.05)$, 
Table I. Flow cytometric data showing the effect of $\mathrm{As}_{4} \mathrm{~S}_{4}$ (25 $\mu \mathrm{mol} / \mathrm{l})$ on Annexin V/PI binding in the NB4-R1 cells.

\begin{tabular}{lccc}
\hline Action time, $h$ & $\begin{array}{c}\text { Viable } \\
\text { cells }\end{array}$ & $\begin{array}{c}\text { Early } \\
\text { apoptotic cells }\end{array}$ & $\begin{array}{c}\text { Late } \\
\text { apoptotic cells }\end{array}$ \\
\hline 0 & $99.53 \pm 0.39$ & $0.00 \pm 0.00$ & $0.08 \pm 0.13$ \\
24 & $60.27 \pm 5.12^{\mathrm{a}}$ & $24.49 \pm 4.05^{\mathrm{a}}$ & $14.72 \pm 1.82^{\mathrm{a}}$ \\
48 & $31.60 \pm 1.48^{\mathrm{a}}$ & $47.41 \pm 4.78^{\mathrm{a}}$ & $20.70 \pm 3.89^{\mathrm{a}}$ \\
\hline
\end{tabular}

${ }^{\mathrm{P}}<0.05$, significant difference compared to the control group. Data are mean $\% \pm \mathrm{SD} ; \mathrm{n}=3 . \mathrm{As}_{4} \mathrm{~S}_{4}$, tetra-arsenic tetra-sulfide; PI, propidium iodide; $\mathrm{SD}$, standard deviation.

\section{A}

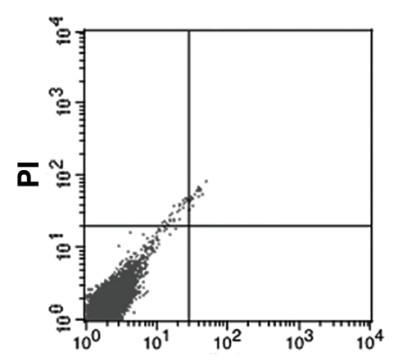

B

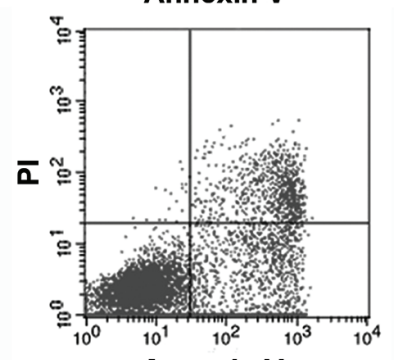

C

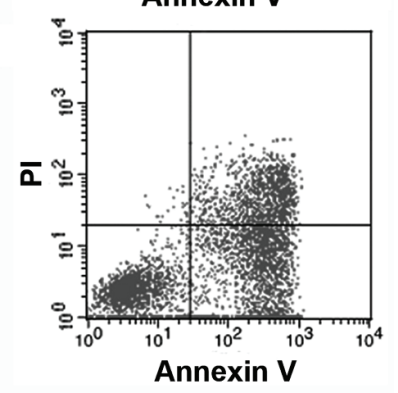

Figure 1. Apoptosis of the NB4-R1 cells treated with tetra-arsenic tetra-sulfide $\left(\mathrm{As}_{4} \mathrm{~S}_{4}\right)$ via flow cytometry. (A) Control; (B) $\mathrm{As}_{4} \mathrm{~S}_{4}$ treatment for $24 \mathrm{~h}$; and (C) $\mathrm{As}_{4} \mathrm{~S}_{4}$ treatment for $48 \mathrm{~h}$. PI, propidium iodide.

respectively. In addition, the percentage of late apoptotic cells (Annexin $\mathrm{V}^{+} / \mathrm{PI}^{+}$, shown in the upper right quadrant) significantly increased from 0.08 to 14.72 and $20.70 \%(\mathrm{P}<0.05)$, respectively. As shown, a progressive increase in the number of apoptotic cells was observed, which suggests time-dependent cytotoxicity (Fig. 1, Table I).

DNA ladder agarose gel electrophoresis was used to distinguish apoptotic cells from necrosis. Apoptosis is characterized by internucleosomal DNA ladder fragmentation through agarose gel electrophoresis to show a 'ladder' pattern at 180 -base pair (bp) intervals due to the activation

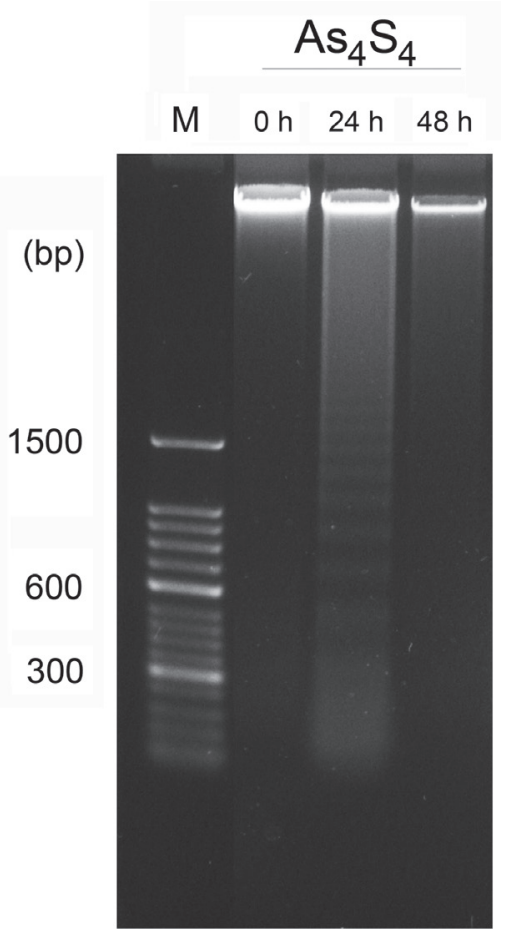

Figure 2. Apoptosis in the NB4-R1 cells treated with tetra-arsenic tetra-sulfide $\left(\mathrm{As}_{4} \mathrm{~S}_{4}\right)$ assessed by analyzing the DNA ladder fragmentation. The NB4-R1 cells were treated for 0,24 or 48 h. M, DNA marker; bp, base pairs.

of endogenous endonucleases, whereas random DNA fragmentation is a typical manifestation of necrosis following electrophoretic separation. The untreated cells contained only high-molecular-weight genomic DNA. Compared with the control group, the NB4-R1 cells inoculated with $\mathrm{As}_{4} \mathrm{~S}_{4}$ exhibited the characteristic pattern of nucleosomal laddering specific to apoptosis, which was visible as faint bands on the gel. $\mathrm{As}_{4} \mathrm{~S}_{4}$ produced DNA fragments of low molecular weight consisting of multimers of 180-200 bp in the NB4-R1 cell line in the 24-h treatment groups. In the 48-h treatment groups, DNA degradation failed to form the typical bands but formed random DNA fragmentation, which indicates necrosis of cells at this time point (Fig. 2).

Effect of $\mathrm{As}_{4} \mathrm{~S}_{4}$ on the proteins associated with NB4-RI cell apoptosis. Based on the above result, the association between apoptosis factor expression and apoptosis induction was investigated in the NB4-R1 cells treated with $\mathrm{As}_{4} \mathrm{~S}_{4}$. The expression of several apoptosis-related factors was studied. Bax levels increased significantly over the control, whereas Bcl-2 showed a clear reduction. All the factors exhibited variations in a time-dependent manner.

As changes of Bax/Bcl-2 have been reported to play significant roles in the activation of caspase signaling, the activation of caspase-3 was detected in the following set of experiments. Incubation of the NB4-R1 cells with $\mathrm{As}_{4} \mathrm{~S}_{4}$ for $24 \mathrm{~h}$ induced activation of caspase-3. Pro-caspase-3 was cleaved into small active fragments of 19 or $17 \mathrm{kDa}$ under apoptotic stimulation. The $113 \mathrm{kDa}$ PARP, as the specific substrate of caspase-3, was cleaved into 89 and $24 \mathrm{kDa}$ fragments after treatment for $24 \mathrm{~h}$. No cleavage of PARP in the control group was detected (Fig. 3). 
Table II. Flow cytometric data showing the effect of $\mathrm{As}_{4} \mathrm{~S}_{4}$ ( $25 \mu \mathrm{mol} / \mathrm{l})$ on the progression of the cell cycle in NB4-R1 cells.

\begin{tabular}{lccc}
\hline Action time, $h$ & $\mathrm{G}_{0} / \mathrm{G}_{1}$ & \multicolumn{1}{c}{$\mathrm{S}$} & \multicolumn{1}{c}{$\mathrm{G}_{2} / \mathrm{M}$} \\
\hline 0 & $57.30 \pm 0.35$ & $31.85 \pm 0.91$ & $10.79 \pm 0.67$ \\
24 & $37.56 \pm 1.85^{\mathrm{a}}$ & $42.53 \pm 2.71^{\mathrm{a}}$ & $19.91 \pm 1.83^{\mathrm{a}}$ \\
48 & $28.51 \pm 2.53^{\mathrm{a}}$ & $55.12 \pm 0.13^{\mathrm{a}}$ & $17.01 \pm 1.44^{\mathrm{a}}$ \\
\hline
\end{tabular}

Data are mean $\% \pm \mathrm{SD} . \mathrm{n}=3 .{ }^{\mathrm{a}} \mathrm{P}<0.05$, significant difference compared to the control group. $\mathrm{As}_{4} \mathrm{~S}_{4}$, tetra-arsenic tetra-sulfide; $\mathrm{SD}$, standard deviation.

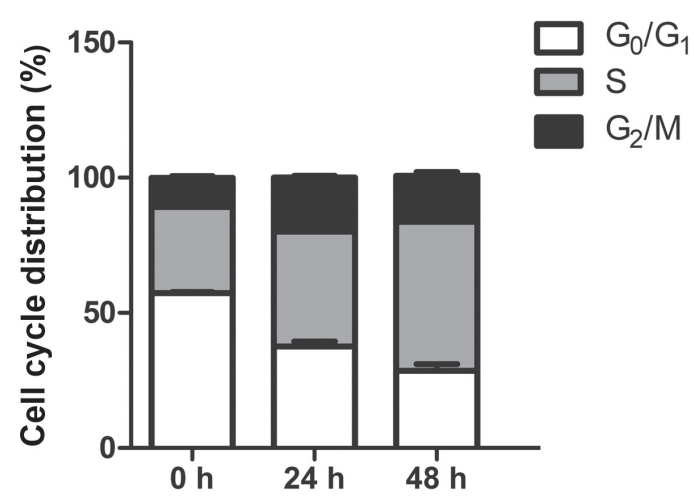

Figure 4. Influence of tetra-arsenic tetra-sulfide on the cell cycle of NB4-R1 cells.

reducing the number of cells in the $\mathrm{G}_{0} / \mathrm{G}_{1}$ phases and arresting the cell cycle in the $S$ phase and $\mathrm{G}_{2} / \mathrm{M}$ phases (Table II, Fig. 4).

\section{Discussion}

APL accounts for $10-15 \%$ of acute myeloid leukemia in adults (1). $\mathrm{As}_{4} \mathrm{~S}_{4}$ has gained importance in the treatment of the APL. Previous studies have shown that the therapeutic action of $\mathrm{As}_{4} \mathrm{~S}_{4}$ is also effective for other tumor therapies $(8,9)$. However, the molecular mechanism of the action of $\mathrm{As}_{4} \mathrm{~S}_{4}$ in RA-resistant APL therapy remains unknown. The present results reveal a time-dependent toxic action of $\mathrm{As}_{4} \mathrm{~S}_{4}$ on RA-resistant NB4-R1 cells. Flow cytometric analyses and DNA ladder agarose gel electrophoresis confirmed that $\mathrm{As}_{4} \mathrm{~S}_{4}$ inhibited tumor cell growth via inducing apoptosis. To probe the cell signaling pathways involved in this $\mathrm{As}_{4} \mathrm{~S}_{4}$-induced apoptosis, the protein expression levels of $\mathrm{Bcl}-2$, Bax, caspase-3 and PARP were detected via western blot analysis.

The Bcl-2 family of pro- and anti-apoptotic proteins plays an important role in apoptosis that is induced by a variety of stimuli. Bcl-2 proteins modulate the integrity of the mitochondrial and endoplasmic reticulum membranes, cytochrome $c$ release, caspase activation and cell death (10). A reduction in Bcl-2 expression can lead to a loss of signals that are required for survival. Bax is a major pro-apoptotic member that is required for apoptotic cell death. Previous evidence has indicated that $\mathrm{Bcl}-2$ can constitute homodimers and heterodimers with Bax, leading to an inhibition of the formation of Bax/Bax pro-apoptotic homodimers $(11,12)$. The ratio between anti-apoptotic and proapoptotic members of the Bcl-2 family may determine the susceptibility of the cell to apoptosis. The present study reported a decrease in Bcl-2 and an increase in Bax following treatment of the NB4-R1 cells with $\mathrm{As}_{4} \mathrm{~S}_{4}$. The decrease in the $\mathrm{Bcl}-2 / \mathrm{Bax}$ ratio leads to the translocation of Bax from the cytoplasm to mitochondria, promoting the release of cytochrome $c$ and the activation of caspase. Variations in the levels of Bax and Bcl-2 can be deduced by apoptosis that is initiated via the intrinsic pathway.

Caspase-3, as the most important executor of apoptosis, participates in DNA degradation, nuclear condensation, plasma membrane blebbing and proteolysis of certain caspase substrates $(13,14)$. Caspases are synthesized as relatively inactive precursors (zymogens) that require proteolytic processing for activation. As discovered in the NB4-R1

These results show that the inhibitory effect on the grow of NB4-R1 cells induced by $\mathrm{As}_{4} \mathrm{~S}_{4}$ was partially mediated by 
cells, $\mathrm{As}_{4} \mathrm{~S}_{4}$ cleaves the $36-\mathrm{kDa}$ pro-caspase-3 into small 17 or $19 \mathrm{kDa}$ active fragments, leading to caspase-dependent apoptosis. Subsequently, the cleaved caspase-3 activates endonuclease caspase-activated DNase, leading to fragmentation of the chromosomal DNA at internucleosomal sites (15). The present results show that cleaved caspase-3 significantly increased after $\mathrm{As}_{4} \mathrm{~S}_{4}$ incubation for $24 \mathrm{~h}$ while the DNA degradation revealed characteristic DNA 'ladder' bands. The activity of this endonuclease can be inhibited by PARP and the cleavage of PARP by activated caspase- 3 reverses the activity of the endonuclease (16). In the present study, the 113-kDa PARP could be cleaved onto an $89-\mathrm{kDa}$ C-terminal catalytic fragment and an N-terminal 24-kDa fragment after $24 \mathrm{~h}$ of $\mathrm{As}_{4} \mathrm{~S}_{4}$ treatment, leading to a loss of DNA repair function.

Various chemotherapy drugs inhibit the growth of tumor cells by blocking the cell cycle. Numerous investigators have reported that $\mathrm{As}_{4} \mathrm{~S}_{4}$ blocks tumor cells at different stages of the cell cycle $(17,18)$. Variations in experimental results may be associated with drug concentration, action time and cell types. In the present study, the accumulation of cells in the $S$ and $\mathrm{G}_{2} / \mathrm{M}$ phases was observed for NB4-R1 cells, suggesting that $\mathrm{As}_{4} \mathrm{~S}_{4}$ may exert its cytotoxic effects on NB4-R1 cells through cell cycle arrest and cell apoptosis.

In conclusion, the present study revealed that $\mathrm{As}_{4} \mathrm{~S}_{4}$, a traditional medicine, inhibited the growth of NB4-R1 cells in vitro. $\mathrm{As}_{4} \mathrm{~S}_{4}$ induced cell apoptosis through changes in Bcl-2 and Bax, activation of caspase-3 and cleavage of PARP. The results suggested the apoptosis of NB4-R1 cells via a mitochondria-dependent pathway. In addition, $\mathrm{As}_{4} \mathrm{~S}_{4}$ may exert its cytotoxic effects on NB4-R1 cells through blocking the cell cycle in the $\mathrm{S}$ and $\mathrm{G}_{2} / \mathrm{M}$ phases. Thus, $\mathrm{As}_{4} \mathrm{~S}_{4}$ may be a potential anticancer drug candidate. The development of cell apoptosis is a multi-factor, multi-step and multi-gene interactive process. The signaling pathways and molecular mechanisms of $\mathrm{As}_{4} \mathrm{~S}_{4}$ in apoptotic regulation require further investigations.

\section{Acknowledgements}

The present study was supported by the Natural Science Foundation of China (grant no. 81000218). The authors would like to express their gratitude to Dr Xinyang Wang for access to the Oncology Research Laboratory, Key Laboratory of Environment and Genes Related to Diseases (Xi'an, China) to complete the experiments.

\section{References}

1. De Braekeleer E, Douet-Guilbert N and De Braekeleer M: RARA fusion genes in acute promyelocytic leukemia: A review. Expert Rev Hematol 7: 347-357, 2014.
2. Lo-Coco F, Avvisati G, Vignetti M, Thiede C, Orlando SM, Iacobelli S, Ferrara F, Fazi P, Cicconi L, Di Bona E, et al; Gruppo Italiano Malattie Ematologiche dell'Adulto; German-Austrian Acute Myeloid Leukemia Study Group; Study Alliance Leukemia: Retinoic acid and arsenic trioxide for acute promyelocytic leukemia. N Engl J Med 369: 111-121, 2013.

3. Fenaux P, Chevret S, Guerci A, Fegueux N, Dombret H, Thomas X, Sanz M, Link H, Maloisel F, Gardin C, et al: Long-term follow-up confirms the benefit of all-trans retinoic acid in acute promyelocytic leukemia. European APL group. Leukemia 14: 1371-1377, 2000.

4. Westervelt P, Brown RA, Adkins DR, Khoury H, Curtin P, Hurd D, Luger SM, Ma MK, Ley TJ and DiPersio JF: Sudden death among patients with acute promyelocytic leukemia treated with arsenic trioxide. Blood 98: 266-271, 2001.

5. Lu DP, Qiu JY, Jiang B, Wang Q, Liu KY, Liu YR and Chen SS: Tetra-arsenic tetra-sulfide for the treatment of acute promyelocytic leukemia: A pilot report. Blood 99: 3136-3143, 2002.

6. Zhu HH, Wu DP, Jin J, Li JY, Ma J, Wang JX, Jiang H, Chen SJ and Huang XJ: Oral tetra-arsenic tetra-sulfide formula versus intravenous arsenic trioxide as first-line treatment of acute promyelocytic leukemia: A multicenter randomized controlled trial. J Clin Oncol 31: 4215-4221, 2013.

7. Qi J, Zhang M, He P, et al: Establishment of two-dimensional electrophoresis proteomic profiles of retinoid acid resistant human acute promyelocytic leukemia NB4-R1 cells with apoptosis induced by realgar. Chin J Integr Med 31: 391-396, 2011.

8. Wang XB, Gao HY, Hou BL, Huang J, Xi RG and Wu LJ: Nanoparticle realgar powders induce apoptosis in U937 cells through caspase MAPK and mitochondrial pathways. Arch Pharm Res 30: 653-658, 2007.

9. Tse WP, Cheng CH, Che CT, Zhao M, Fan RQ and Lin ZX: Realgar-mediated growth inhibition on $\mathrm{HaCaT}$ human keratinocytes is associated with induction of apoptosis. Int J Mol Med 24: 189-196, 2009.

10. Rong Y and Distelhorst CW: Bcl-2 protein family members: Versatile regulators of calcium signaling in cell survival and apoptosis. Annu Rev Physiol 70: 73-91, 2008.

11. Brajusković G, Orolicki SV, Cerović S, Usaj SK, Marjanović S and Romac S: Bcl-2 and Bax protein interaction in B-lymphocytes of peripheral blood in patients with chronic lymphocytic leukemia. Vojnosanit Pregl 62: 357-363, 2005 (In Serbian).

12. Martinou JC and Youle RJ: Mitochondria in apoptosis: Bcl-2 family members and mitochondrial dynamics. Dev Cell 21: 92-101, 2011.

13. Sikdar S, Mukherjee A, Ghosh S and Khuda-Bukhsh AR: Condurango glycoside-rich components stimulate DNA damage-induced cell cycle arrest and ROS-mediated caspase-3 dependent apoptosis through inhibition of cell-proliferation in lung cancer, in vitro and in vivo. Environ Toxicol Pharmacol 37: 300-314, 2014.

14. Tong X, Han X, Yu B, Yu M, Jiang G, Ji J and Dong S: Role of gap junction intercellular communication in testicular leydig cell apoptosis induced by oxaliplatin via the mitochondrial pathway. Oncol Rep 33: 207-214, 2015.

15. Bayascas JR, Yuste VJ, Solé C, Sánchez-López I, Segura MF, Perera R and Comella JX: Characterization of splice variants of human caspase-activated DNase with CIDE-N structure and function. FEBS Lett 566: 234-240, 2004.

16. Boulares AH,Zoltoski AJ, Contreras FJ, Yakovlev AG, Yoshihara K and Smulson ME: Regulation of DNAS1L3 endonuclease activity by poly(ADP-ribosyl)ation during etoposide-induced apoptosis Role of poly(ADP-ribose) polymerase-1 cleavage in endonuclease activation. J Biol Chem 277: 372-378, 2002.

17. Chen WX, Zhang F, Yang HC, et al: The effect of realgar on apoptosis of transplanted ovarian SKOV3 carcinoma cells in nude mice. Tumor 27: 787-790, 2007.

18. Chen SY, Liu SX and Li XM: The dual effects of realgar on acute promyelocytic leukemia cell: Inducing apoptosis and promoting differentiation. J Xi'an Jiaotong Univ 23: 401-404, 2002. 